\title{
What should we teach children about forgiveness?
}

\author{
Alonso: But, O, how oddly will it sound, that I \\ Must ask my child forgiveness? \\ Prospero: There sir stop, \\ Let us not burthen our remembrances, with \\ A heaviness that's gone. \\ (Shakespeare, Tempest, V,I)
}

In 1998 the president of the Bible Society called on the nation to forgive David Beckham for getting himself sent off in England's World Cup match against Argentina, after it was reported that in a TV poll $40 \%$ of fans said they could not forgive his foul (The Guardian, 13 July, 1998). ${ }^{1}$ In 1999 President Clinton asked God, his wife and the American people for forgiveness for lying about his relationship with Monica Lewinsky. The Pope, perhaps helpfully for Beckham and Clinton, declared 2000 to be a special Holy Year, a year of forgiveness, freeing sinners from time in purgatory (The Guardian, 28 November 1998). We seem to live in a culture of forgiveness in which there is pressure on wrongdoers to seek forgiveness and on others to forgive them. How far should this be reflected in the way we educate children? Should teachers and parents teach children to forgive one another? The Primary and Secondary Handbooks on the National Curriculum both include under the entry about the promotion of moral development across the curriculum the statement that children should 'learn how to forgive themselves and others' (Handbook for Primary Teachers, DfEE/QCA, 1999: 19; Handbook for Secondary Teachers, DfEE/QCA, 1999: 21). But what is involved in encouraging forgiveness? Is it an unambiguous notion? Is there even a danger that it could involve fostering in children some ethically questionable attitudes? 
Forgiveness is one response to having been wronged. If I suffer some wrong, there are a number of possible attitudes and actions I can take. I can attempt to take my revenge. Or perhaps too pusillanimous or too circumspect for that, I can content myself with nursing a grudge. Or I may decide to leave the matter to another agency, say to the workings of karma which will take care of the wrong doer for me (cf Elder, 1998: 158). Or it may seem to me that the best revenge is living well, and I robustly shrug off the wrong done and ignore the wrong doer. Or perhaps, more constructively, I may choose to see the situation in a more forward-looking way as something from which the wrong-doer and I must now move on. Alternatively, I may forgive the wrongdoer. If I decide on the last course what is involved?

\section{Forgiveness: the strict view}

\section{What is forgiveness?}

There is a strict view of forgiveness. First, what it is not. On this view, forgiveness is not excusing or justifying the wrongdoer. Typically, excusing is the attitude of grandparents who redescribe their grandchildren's actions, 'No, you didn't want to hurt grandpa when you climbed on him, did you? I think you were just seeing if he was ready to play.' Given this redescription there is nothing to resent and nothing to forgive. The need for forgiveness is preempted.

Showing mercy is also not to be confused with forgiveness. In showing mercy I am simply treating you less harshly than I have a right to (not forgiving you), as, classically, Portia urges Shylock to do in the case of the pound of flesh.

Calhoun (1992: 80) suggests that wrongdoers want forgiveness 'for the culpability that remains after excuses, justifications, restitution, and repentant reforms have been made and accepted-a culpability that warrants our continuing to be resented.' 
Forgiving, on this view, means giving up resentment towards the wrong-doer, but not just giving up resentment, but knowingly doing so and in the light of some more significant value. A person may not nurse resentments because she tends to forget the slights and injuries which occasioned them. But forgetting is not forgiving. And simple forgetting is not what the wrong doer wants. What the wrong doer genuinely seeking forgiveness wants is to be reinstated in the thoughts of the person he has wronged, to occupy the place in those thoughts which he always has done. In intimate relationships he wants to be looked on with the same loving fondness as before the offence. He wants the person wronged once again to be naturally on his side when she thinks of him in relation to others. With less intimate relationships the wrong doer wants the person he has wronged at least not to think of him bitterly and with resentment and always in association with the offence. Ideally, he wants the person wronged to be able to think of him again apart from his offence.

But can a person wronged give up his resentment towards the person who has harmed him? Such feelings, of perhaps annoyance, anger or hatred, can be seen not simply as primitive reactions to hurt, much as a dog snarls at a blow, but as defensive of basic ethical values (cf Bishop Butler, 1958, 'Upon Resentment': 120132). For if a person is attacked physically, or in some other way, he is not being respected as a moral being. If he has any self-respect at all therefore, he feels affronted. In much the same way as he would feel indignant if this treatment were meted out to someone else. Can he give up these ethically grounded feelings?

The strict view has a conception of what constitutes a worthy case for forgiveness. On this view sincere repentance by the wrongdoer is required, without qualification, and (if appropriate) with reparations. For if the wrongdoer is truly repentant, he is in effect now taking the same ethical stance as the person wronged, the victim. He sees his wrong doing as reprehensible, he understands that his victim was justified in feeling hurt and affronted and is anxious to make amends. Not only does the 
victim have an appropriate reason for forgiveness, but perhaps, given this change of heart on the part of the wrongdoer, the victim has a duty to forgive him. But this seemingly standard and central case of forgiveness has been challenged. Kolnai (1978: 217) raises the question of whether in the case of the repentant wrongdoer forgiveness is pointless. It has lost its raison d'être because there is nothing to be forgiven. The wrongdoer has separated himself from his wrongdoing and regards it in the same light as the victim. So, in giving up his feelings of resentment the victim is doing no more than is rational in that the wrongdoer is no longer a wrongdoer. At the same time, however, as Kolnai argues, the repentant wrongdoer is not discontinuous with the person who caused me the harm. He was responsible for it. So the point of the act of forgiveness is to put the relationship on its previous footing. The wrong cannot be eliminated but by forgiving the perpetrator, the person wronged is making it clear that he is not just prepared to forget the offence but he wants to put the relationship on its former footing. The wrong doer is to be reinstated in his thoughts and to occupy just the place he did before.

What is it, then, on the strict view to have forgiven someone? Central to the notion is that, in the interests of getting on together again, the victim wipes the slate clean reinstates the wrongdoer in his thoughts with whatever degree of affection or respect he held him in before being wronged. A condition of this reinstatement is that the wrongdoer sincerely repent. There is a performative aspect to strict forgiveness, which involves actually saying 'I forgive you' or something very close to it. A victim might say this because he thinks it right to do so, whilst he is still trying to bring his feelings into line with his words. Then there is the behavioural aspect which might involve, for instance, not expressing rancour to the offender, not continuing to mutter about the wrong with others. Finally, there is the emotional state. A victim might eventually discover that he has forgiven the offender when he realises that he can now think of him without bitterness. 


\section{Problems with the strict view of forgiveness}

Is forgiveness in the strict sense a virtue to be universally encouraged?

Problems can arise about the attitudes and assumptions of both the victim and the offender.

\section{The victim}

What does the strict view say of a victim who will not, or cannot, forgive? What if a person cannot bring herself to say that she forgives, or produce the appropriate behaviour, much less feel the appropriate emotions? There may be victims who, even faced with a sincerely repentant person, are not willing to forgive. Are they to be deemed irrational or morally blameworthy? Dickey (1998) describes the case of the victim of a particularly horrifying rape at gun point. Subsequently, the victim's marriage ended in divorce because her husband believed that she was complicit in the rape and her husband won custody of their adopted seven year old daughter. The daughter had had to have therapy because she blamed herself in part for the rape, reasoning that if she had been at home it would not have happened. The victim herself had been admitted to mental hospital three times, on one occasion following what doctors believed to be a suicide attempt. It also seems that because of the drugs used in her treatment, she had suffered some memory loss. Thus she had lost her husband and family and the whole world of her life before the rape. She was now unable to enjoy even simple pleasures, like long solitary walks in the country. At a meeting arranged with her attacker the woman stated that at the moment forgiveness was not possible for her. She felt that nothing could compensate her for the devastation the rape had caused in her life and she felt huge resentment towards her attacker. She hoped perhaps in the future to be able to forgive him. 
It is important to say, first, that the victim finds it hard to accept the assurances of her attacker that he is indeed remorseful. As she is reported as saying 'it is a bit hard for her to believe all that, coming from a guy who had stuck a gun in her mouth and told her to count the shells' (Dickey, 1998: 112). But even if she were to be convinced of his sincere repentance there is still another factor. The victim has suffered a great wrong and continues to suffer and the wrongdoer seems by contrast (and in this instance the victim refers to this several times) to be having a much easier time. Thus, in so far as justice is concerned with desert, the situation seems terribly unjust and the albeit currently repentant wrongdoer is indeed continuous with the person who brought about this state of affairs. On the strict view this victim should be urged to express forgiveness, produce the appropriate behaviour and strive to bring her feelings into line and forgive her attacker. But can it be argued that she has a moral duty to do so? Or even that it is ethically desirable that she should? There are, after all, other options. Leaving aside, for the moment, the ethically questionable option of revenge, there is the possibility of attempting to forget rather than forgive. This may be difficult but perhaps less painful than forgiveness, which requires the victim to continue to dwell on unpleasant aspects of the experience. Can this option be shown to be morally inferior to that of forgiveness?

Even, then, in the seemingly most straightforward case of a victim faced with a sincerely repentant wrongdoer the strict view of forgiveness seems to raise problems. But these are not the only problems it raises.

Forgiveness on this strict view is, as we have seen, a matter of reinstatement. Its point is that it makes it possible to go on together (Calhoun, 1992:96), to "re-accept" somebody' (Kolnai, 1977: 222). It is a 'healing and restoring virtue' (Murphy 1990: 32). In some cases the wrongdoer will be restored to his place in a loved one's affections and in others, in cases of relationships between strangers or relations in 
the workplace, there will be a more mundane form of reinstatement. Forgiveness, all in all then, makes possible reacceptance into a relationship or a community.

There are two points to make. The first is more trivial. Does the notion of reacceptance, and hence forgiveness, make sense in some cases? The phrase 'going on together' perhaps fits some aspects of family life, the classroom and the workplace, although there might be some doubts even here. But if the injury, a robbery or a rape say, is inflicted by a stranger, in what sense do victim and wrongdoer have to go on together? In many cases they will not live or work in close proximity and may never need to see one another again so, in one sense, they will not be going on together because they were not going anywhere together before. The only sense in which they were, and are, going on together may be as members of the same national community. In the case outlined earlier, for instance, perhaps it is something of a nonsense to ask the woman to 'reinstate' the offender. Matters may well go worse for her as she tries and fails to do this and then feels guilty about her seeming lack of charity. This, as already suggested, is perhaps a trivial point as it could be argued that all it shows is that sometimes the notion of forgiveness is applied in contexts in which it has no place.

A perhaps more important consideration is that to talk of reinstatement or reacceptance is to assume a framework in which if someone does something wrong they are in some sense 'beyond the pale'. They are outcasts, they are excluded from civilised society. Is this a framework in which it is ethically desirable to operate? It perhaps fits a world view which needs to separate sinners from saved but does it fit a secular world view which has no need to make a distinction between the sheep and the goats (Bible, Matthew, XXV 31-46)? A case might perhaps be made for thinking in this way of moral monsters, the Hitlers, the Pol Pots, the serial killers, thus literally marking off a category of those operating outside the bounds of any 
civilised society. But is it ethically desirable to think like this about all people who have wronged us, even if badly?

Operating on the strict view with categories of sinners and (at least presently) nonsinners creates further ethical problems. There is worry in the literature (Kolnai, 1977; Taylor, 1985; Hampton in Hampton and Murphy, 1990, 39-40) about those who generously forgive, and thus reaccept the wrongdoer when the wrongdoer is not remorseful. Does this attitude, some suggest, not condone the wrongdoing? In reaccepting the unrepentant wrongdoer, it is claimed, the victim seems to think little of the wrong done and thus compromises his own values. Unrepentant goats must not be treated as sheep.

Forgiving, and reinstating the unrepentant, also seems to raise problems of what might be called moral imperialism. A father may come to forgive his gay son for the hurt his son's sexual orientation and practices have caused him. The son may find his father's attitude comically arrogant. Sometimes offers of forgiveness will seem insultingly patronising.

\section{The offender}

The attitudes and assumptions attributed to the offender within the strict forgiveness view also raise problems.

What does the person genuinely seeking forgiveness want? The spirit of forgiveness from the point of view of a penitent wrongdoer is captured in the fervent, yet hopeless, wish we have as children that the clock can be put back, that the wrong can be wiped out, that things can be as though we had never done the terrible thing. The seeker after forgiveness, in this sense, wants something magical. And indeed, it can be argued, this is what the Christian notion of forgiveness is offering. But it is 
offered at a price. The seeker after forgiveness, for instance, is focussed on himself. Is this a desirable focus for ethical attention? Or is it self-indulgent?

It is possible to see a Chekhov story as a farcical illustration of the self-indulgence of the seeker after forgiveness. Chervyakov,the subject of Chekhov's short story 'Death of an Official', sneezes at a theatre performance and recognises General Brizhalov from the Department of Transport in front of him carefully wiping his bald head. He immediately apologises and the general makes a 'think nothing of it' response. Uncertain, Chervyakov apologises again in the interval and gets a similar gracious response from the general. Still thinking that the general may yet, despite his courteous remarks, be affronted, he goes to the general's office and attempts a third apology. For the general, preoccupied with his business, this is becoming tiresome and he is rather brusque, even suggesting that Chervyakov is having some sort of joke at his expense. This prompts yet another attempt at apology from Chervyakov .... An ingrained servile attitude to a bureaucratic superior makes it impossible for Chervyakov to think that the slate can be so easily wiped clean and that he has been reaccepted. Chervyakov's many attempts at apologies finally result in his having a fatal seizure. Is it too fanciful to see this tale as an exaggerated case of the self-indulgence of the seeker after forgiveness?

These considerations raise questions about whether we can, without qualification, teach children that they should forgive people who have wronged them. It seems to me from my reading, both academic and popular, that it is universally taken for granted that forgiveness is a virtue which everyone should try to cultivate. Two recent encyclopaedia entries on forgiveness, for instance, state unequivocally that 'forgiveness and mercy are obvious virtues' (Honderich, 1995: 289) and forgiveness is 'an essential element of all personal relationships' (Routledge, 2000: 284) But perhaps in encouraging this virtue in children, on the strict view of forgiveness, parents and teachers are fostering attitudes which are at least ethically questionable. 
On this view, accepting the duty of forgiveness seems to involve taking on the following attitudes. There is, first, the assumption that wrongdoers have excluded themselves by their actions from relationships and communities into which they now have to be reaccepted. Is that an attitude that it is always desirable to take to someone who has done some wrong? Interestingly, as noted earlier, it is an attitude generous-hearted people often avoid by redescribing what has been done and excusing it. Indeed this is what Jesus Christ on the cross does in saying 'Father, forgive them; for they know not what they do.' Strictly speaking, if they know not what they do,they do not need forgiveness, they are exonerated from blame. There is, second, the question of the standards being employed. Perhaps the wrongdoers do not see themselves as such. Also, do we want wrongdoers to focus their attention on being forgiven? It might seem more appropriate for them to focus on how to move forward from their wrongdoing by making amends (if possible), apologising, even perhaps, in the light of the last point, convincing others that they are not wrongdoers.

Additionally there may be a problem of integrity. Forgiveness is a central feature of the Christian religion and a prominent Christian virtue. After the Fall and the descent of mankind into sinfulness, with Jesus Christ comes the Atonement. This brings the possibility of forgiveness for sinful human creatures who in turn are commanded to forgive one another (Bible, Matthew 6:12). But how far can a non-Christian fit into this narrative without the uneasy feeling that she is playing a part in a drama with which she cannot wholeheartedly identify?

If there are these sorts of problems with the strict view of forgiveness, is it possible, perhaps even ethically desirable, to dispense with this view?

\section{A world without strict forgiveness?}


But what would a world be like in which people were not encouraged to feel they had a duty to forgive in this sense? And perhaps were not even encouraged to feel that it would at least be good if they forgave people who had wronged them? Would it not be a less good world? Would it not it be a world in which people sought vengeance, nursed grudges, remembered long past wrongs and were determined that people should suffer endlessly for the wrong they had done?

\section{'No Problem!'}

It does not have to be like this. There is the possibility of departing from the strict view, by relaxing its stringent criteria for cases of forgiveness. Forgiveness in this more relaxed sense is a matter of having a different perspective on wrongs we experience, not a fancifully invented one, but one which to some extent we already have. It is a matter of thinking that we all make mistakes, we are all tempted from time to time to do things we later regret, we get frustrated and lose our tempers, we are spiteful and mean-spirited and the catalogue could go on. In the ordinary and minor vicissitudes of everyday life there is every reason to do what we can to repair hitches and snags in relationships without making a song and dance of it. As I have suggested this is not an attitude wholly alien to the way we live. It is expressed in remarks like 'There but for the grace of God . . .', 'Least said, soonest mended,' 'We all make mistakes!', 'Easily done!'

There is nothing in this more relaxed notion of forgiveness about the restoration of the status quo ante, about sincere repentance, about accepting someone back from beyond the pale. Like the more stringent view, its point is to enable people to get on together again, but it seeks another way of doing this. Parents, older siblings and teachers initiate young children into the whole practice of patching and repairing relationships and negotiating one's way back into them. Young children learn to say that they are sorry and how to say it in different contexts. Typically a lot of time in families, nurseries and infant schools is taken up with helping children to do this. At 
the same time it is a matter of encouraging children who have been hurt by remarks or actions of their fellows to accept that it is churlish and ungenerous not to accept a sincere apology or an attempt to make amends. To put it rather crudely, this is the beginning of a 'No problem!' rather than a 'God may forgive you, I never will' culture. It is a matter, on the one side, of encouraging a willingness to apologise and make amends (if possible) combined, on the other, with a generous acceptance of people who have caused one hurt. Unlike the hierarchical relationship of strict forgiveness this is a relationship which obtains between equals. It is not a matter of reinstatement because the offender was never seen as beyond the pale but simply as having made a mistake, done something wrong.

To call this way of proceeding 'the more relaxed' notion of forgiveness is to make the point that it does not require the criteria for strict forgiveness. It is not to say that this kind of forgiveness is always easy. It may be straightforward enough to say 'Easily done!' when someone carelessly opens a door in your face but what about the person who finds out that his wife is sleeping with his best friend? This particular turn of phrase may not be the one that most readily comes to mind but there is no reason why the basic attitude should not be the same. There has been a breach of trust but such things happen and if he loves his wife he may well want to restore harmonious relations if that is what she wants. Of course the situation is inevitably complicated by all the other attitudes in play, like feelings of jealousy, loss of self-esteem and so on. But that does not preclude a attitude which allows the restoration of harmony, even if with difficulty, without an insistence on the stricter criteria for forgiveness. ${ }^{2}$

But how far should we assume, along with both cases of forgiveness, that peace and harmony must be restored? Perhaps sometimes we have to live with conflict and damage. Hampshire may well be right that 'Neither in a social order, nor in the experience of an individual, is a state of conflict the sign of a vice, or a defect, or a malfunctioning' (Hampshire, 1999:40). Perhaps when faced with gross breaches of 
trust and similar offences it is important to realise that there are several ethically acceptable options. Faced with the wrong, a person might feel that it is impossible to go on with these people. A parting of the ways is the best solution. In this case, forgiveness does not come into the picture. Alternatively, all parties might look at the situation and see what, starting from where they are now, they might construct for the future. This would be to follow forgiveness in the relaxed sense. There are ethically acceptable possibilities which do not involve going down the route of the strict view of forgiveness.

If one rejects the strict view, has one thereby rejected the Christian view of this virtue? Not necessarily, because there is not a monolithic Christian view. The Bible offers several examples of the more relaxed view as an acceptable response to wrong-doing. Jesus does not urge the woman taken in adultery to atonement, penitence or reparations he simply says 'go, and sin no more.' Also his invitation to cast the first stone does not suggest that the world can be divided into those who sin and those who do not (Bible, John VIII, 3-11). The father doesn't wait to hear about his prodigal son's state of mind before rushing to greet him (Bible, Luke, XV, 11-32). Neither is the unforgiving servant called upon to repent his misdeeds before he is released from his debts (Bible, Matthew, VIII, 21-35). It would be interesting to see where the stricter view of forgiveness came from. Certainly by the Middle Ages the church had a whole culture of sin, repentance, penances, indulgences and forgiveness, the seamier side of which appears, for instance, in the character of Chaucer's Pardoner. What forces produced this powerful mechanism of social control and held it in place in various forms down to the present time? Also, why has the strict view now become the 'standard' view discussed in contemporary philosophical and psychological texts? These historical and sociological questions, however, cannot be pursued here. 


\section{Education and forgiveness}

Standard philosophical works commend forgiveness. Government documents urge that children be encouraged to practise it towards themselves and others. A QCA scheme of work in Religious Education suggests that children discuss questions like: What is it that makes forgiving someone difficult? Is forgiving more difficult than holding a grudge? Can punishment and forgiveness be linked? How should we seek forgiveness from another?(Religious Education, DfEE/QCA, 2000: Unit 5D) But these questions seem to take for granted that children and their teachers understand what forgiveness is and do not see it as problematic. But forgiveness, as I have tried to show, is not a straightforward notion. There are significantly different conceptions of forgiveness. Furthermore, how far any of them is always the most ethically appropriate attitude to take to a wrong doer is questionable.

Thus, understanding the idea of forgiveness will have to precede plunging into discussions about how we seek it, show it etc. It will involve looking critically at its strict and more relaxed versions (and possibly others too) at an appropriate stage in education. It may include appreciating that the Christian tradition does not have a monolithic notion of forgiveness; both attitudes presented in this paper can be traced through its texts and history. This exploration could well be extended to other traditions. As far as I understand them, for instance, Confucius's teachings seem to tend towards the relaxed view.

There is a further aspect to the project of understanding attitudes to wrong-doers. As children became mature enough, it would need to be made clear that in the case of gross physical or emotional damage, a person can take a number of different attitudes to the person who has injured them. A significant part of moral education at this stage would need to involve an examination of the ethical considerations and assumptions surrounding these options. Apart from the possibility of explorations 
based on personal experience, there is a wealth of literature and film in which themes of forgiveness, revenge and other attitudes are portrayed.

But what attitude to forgiveness should be actively promoted in the life of the school and classroom? The dominant one in the education of young children, I would argue, would be the promotion of the generous-spirited attitude between equals implicit in the relaxed view and well suited to a liberal democratic multi-ethnic society. The strict view of forgiveness carries much questionable baggage with it which would rule it out as a possible foundation for a policy in the common school. The 'no problem!' conception can be promoted on its own terms, without explicit reference to any religious tradition (even if, as we have seen, it is compatible with some Christian biblical teachings). It can simply be advocated as a practice which is likely to limit conflict and disharmony in the school and promote a co-operative ethos. Unaligned with any religious tradition, it is a practice which anyone prepared to live by democratic values can find congenial. It is egalitarian in its attitudes to victim and wrongdoer and has the overall aim of the promotion of harmonious living.

If there is any substance in this sceptical look at the strict view of forgiveness and the claim that other attitudes may be more ethically acceptable, this has significance for personal relations and for the establishment of a harmonious, co-operative ethos in schools in a democratic multi-ethnic society. It may have even greater significance for political communities involved in longstanding conflicts. But that must wait for another paper. 


\section{Notes}

1. I am hugely indebted to Ray Elliott for discussing several versions of this paper with me. I am also grateful to John White for many discussions about forgiveness and to Jin Sheng Hong for comments on traditional Chinese notions of forgiveness. Thanks are due as well to the anonymous reviewers of this paper for encouraging me to clarify further the central distinctions.

2. That this is possible, even in the most difficult cases, is shown by the example of Beate Raedergard, the mother of the Norwegian girl, Silje, who was killed by her school friends. She surprised a British reporter, who clearly had the James Bulger case in mind, by saying, six years after the killing, that she had forgiven the boys who did this long ago (The Guardian, 30 October 2000). 


\section{Bibliography}

Butler, Joseph Fifteen Sermons, London, G. Bell \& sons Ltd, 1958.

Calhoun, Cheshire (1992) 'Changing One’s Heart' Ethics 103 (October 1992) 76-96.

Chekhov, A (1985) 'Death of an Official' in Tales, Simferopol, Tavria Press.

Concise Routledge Encyclopedia of Philosophy, Routledge, 2000.

Confucius (1996) Analects, Beijing, Sinolingua

Dickey, Walter J (1998) 'Forgiveness and Crime: The Possibilities of Restorative Justice' in Robert D Enright and Joanna North (eds.) (1998) Exploring Forgiveness, Wisconsin, University of Wisconsin Press.

Elder, Joseph W (1998) 'Expanding Our Options: The Challenge of Forgiveness' in Robert D Enright and Joanna North (eds.) (1998) Exploring Forgiveness, Wisconsin, University of Wisconsin Press.

Hampshire, Stuart (1999) Justice is Conflict, London, Duckworth.

Honderich, T (ed.) (1995) The Oxford Companion to Philosophy, Oxford, Oxford

University Press

Kolnai, A (1977) Ethics, Value and Reality, London, The Athlone Press.

May, S (1999) Nietzsche's Ethics and his War on 'Morality', Oxford, Clarendon Press.

Murphy, J G and Hampton J (1990) Forgiveness and Mercy, Cambridge, Cambridge University Press.

The National Curriculum: Handbook for Primary Teachers in England, DfEE/QCA, 1999.

The National Curriculum: Handbook for Secondary Teachers in England, DfEE/QCA, 1999.

Reed, John R (1995) Dickens and Thackeray: Punishment and Forgiveness, Athens, Ohio University Press.

Religious Education: A scheme of work for key stages 1 and 2, DfEE/QCA, 2000.

Smith, Tara (1997) 'Tolerance and Forgiveness: Virtues or Vices?' Journal of Applied Philosophy, Vol 14, No 1. 
Taylor, G (1985) Pride, Shame and Guilt: Emotions of Self-Assessment, Oxford, Clarendon Press.

Wilson, Edward O (1978) On Human Nature, London, Harvard University Press. 